\title{
A LOW-COST SOLAR FARM MONITORING SYSTEM BASED ON CLOUD DATABASE
}

\author{
Fawzi Al-Naima
}

Al-Mamoun University College, Dept. of Computer Eng., Baghdad, Iraq

\author{
Abdullah Hamad \\ Al-Nahrain University, Dept. of Computer Engineering, Baghdad, Iraq \\ OMESTE \\ JEL Category: 013, Q42
}

\begin{abstract}
Renewable energies have become important sources of electricity generation in modern times, with solar energy being one of the best types of such energy since solar radiation can be converted directly into electricity. To harness the solar energy in the best way, specialists in this field resort to solar farms where a large number of solar panels are installed in an open area and the electricity produced is being transferred into towns. The design of a reliable monitoring system for such a large number of solar panels becomes an essential part of such design to reach the needed efficiency. This paper introduces a low-cost practical implementation of a monitoring system for an existing solar system installed on the building of the Ministry of Science and Technology (MST) in Baghdad based on Wireless Sensor Network (WSN) technique. The "ThingSpeak" cloud database is utilized to store and retrieve the monitored data and the PHP and HTML programming languages are used to design a Graphical User Interface (GUI) to display these data.
\end{abstract}

Keywords: Monitoring System, Solar System, Cloud database, PHP, WSN, Big data, solar farm

\section{INTRODUCTION}

In recent years, solar energy has become one of the best choices of electric power generation in comparison to other sources such as oil in terms of cost, noise production, and air pollution. However, this source needs to be maintained periodically to get high performance of panels that are used in such system (Papageorgas et al., 2013) (Nagalakshmi, Babu, \& Prashanth, 2014). Solar panels can be exposed to many faults that lead to the reduction of energy produced. These

Address of the corresponding author:

Fawzi Al-Naima

䒠=Fawzi.alnaima@ieee.org faults may occur due to several factors such as dust, shading as well as cutting in the wire leads thus reducing the efficiency of solar panels (Tejwani, Kumar, \& Solanki, 2014) (Guerriero et al., 2014). In order to detect faults in a short time, a monitoring system should be designed for the solar panels where sensors are installed on PV panels and the nodes collect data and send them to a central monitoring room. This solution will reduce the cost and effort of measuring solar system parameters (Purohit, 2015) (Thangarajah, Wongkaew, \& Ekpanyapong, 2014). An effective monitoring system should send alarm messages to the central room in the case of a fault being detected in a solar panel. Any solar system must be followed by a control system to obtain the 
highest possible efficiency (Banu I-V, 2012). A monitoring system for a solar farm can provide information about the panels operational conditions and suggest solutions to improve their performance. These solutions may reduce effort and cost to discover the error occurrence in the solar farm systems. In addition, the monitoring system should provide solar farm information in a simple form that enables the user to interpret them easily (Bellia, Youcef, \& Fatima, 2014) (Mohapatra, Nayak, \& Mohanty, 2013).

\section{SOLAR SYSTEMS}

Solar systems have become an essential part of the production of electric power in many countries worldwide. One of the most important impediments to such systems is low efficiency. It is necessary to understand the mechanism of work in detail before taking the necessary actions to increase the system efficiency (Banu I-V, 2012). Before designing any monitoring system, we should study the characteristics of the components that we try to monitor. The main part of the solar panel is the solar cell. Connecting a set of solar cells to be a module and modules are grouped to form an array. A photovoltaic panel consists of a set of many arrays as depicted in Fig. 1 (Banu I-V, 2012).

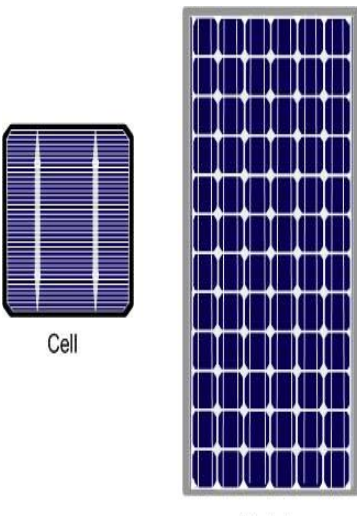

Module

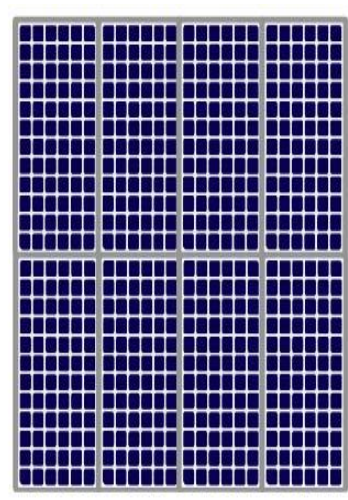

Array
Fig. 1 Photovoltaic hierarchy

The connection of cells in the module is similar to the connection of a module in the array. To increase the voltage of the panel, we should connect modules in series form and increase the current of the panel, modules should be connected in parallel. The efficiency of panels depends on the irradiance distribution on the panel. Parameters of $\mathrm{PV}$ panels are given in datasheet supplied by the manufacturer. The datasheet provides characteristics of PV panel such as short circuit current and open circuit voltage and standard test conditions and other design characteristics (Abid, Abid, Obed, \& AlNaima, 2018). The standard test conditions are irradiance equals to $1000 \mathrm{~W} / \mathrm{m}^{2}$ and temperature equals to $25^{\circ} \mathrm{C}$.

\section{SYSTEM DESIGN}

A WSN is a network that consists of multiple nodes distributed in an open area for monitoring environment or any physical conditions (Matin \& Islam, 2012). The WSN has a gateway that provides wireless connectivity to the wired network and these distributed nodes as shown in Fig. 2 (Zhang, Wu, Han, \& Yu, 2017). Selecting a wireless protocol depends on the desired application (Kaur \& Kaur, 2017).

The proposed design consists of two parts. The first part is a client that consists of hardware components such as voltage sensors, current sensors, temperature sensors and humidity sensors that read PV panel parameters and WSN modules to send these data to the cloud database. The voltage divider is used to measure the voltage of each panel (Desmond, Seng, \& Leong, 2016), a current sensor type ACS712 is used to measure the current produced by each string of four panels connected in series, and humidity and temperature sensors type DHT11 are used to record the humidity and temperature of the solar farm (Tomar \& Basak, 2016) (Kandil et al., 2011). The second part of the system is a server where users can log in to display monitored data via graphic user interface designed with PHP and HTML. ThingSpeak Cloud database is used to store and retrieve sensors data. The ThingSpeak is a platform of the Internet of Things (IoT) that enables users to store the sensors data and design IoT applications. The ThingSpeak cloud can receive sensors data via Raspberry $\mathrm{Pi}$, Arduino, NodeMCU, and other hardware components. In this paper, we will use the NodeMCU module to send sensors data to the ThingSpeak cloud. This module has esp8266 WI$\mathrm{FI}$ chip that can connect to the internet. The components used on the server side and client side will be described in the next two sub-sections. 


\subsection{Client-Side Components}

The client side consists of hardware and software components. The hardware consists of $20 \mathrm{PV}$ panels. The PV panels used in this work are installed in the MST with a module named HJM80M-12 that is connected off-grid. These panels are connected in the form of five strings in parallel, with each string consisting of four panels in series as shown in Fig. 3. The proposed monitoring system will be implemented for each string. The system, we will monitor each string with one NodeMCU module. The NodeMCU is a microcontroller that contains a Wi-Fi module to connect to internet gateway with IP address. Arduino IDE software will be used to program the NodeMCU microcontroller. A multiplexer is used to connect all sensors in each string and control the switching between them. The multiplexer used in this design is GD4051B with eight analog inputs. The other component of the client side is an ACS712 current sensor. It is seen as a suitable solution for measuring $A C$ and DC currents. In addition, it is easy for implementation by users. The voltage of each panel can be determined using a voltage divider for each panel. The DHT11 humidity and temperature sensors are used to record the humidity and temperature of the panels.

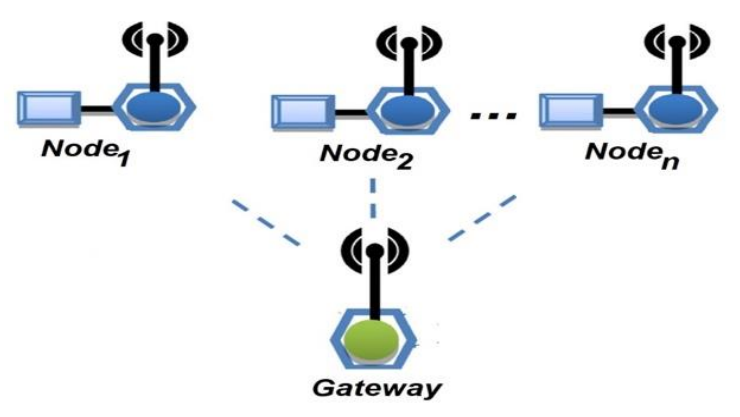

Fig. 2 WSN components

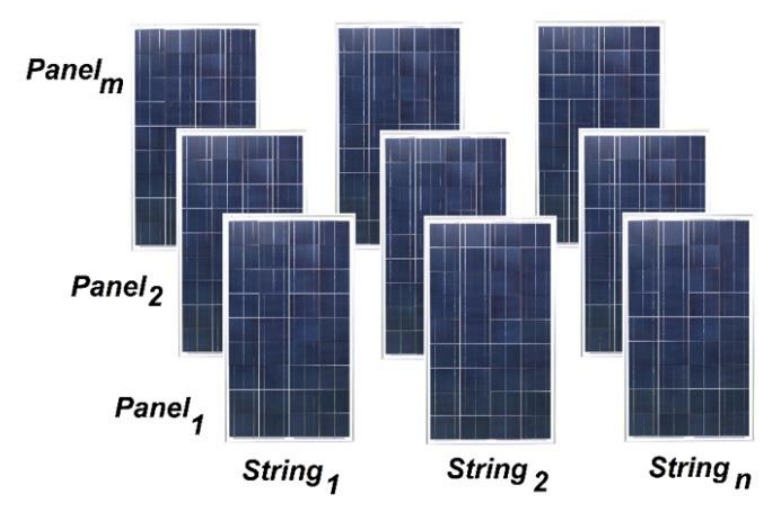

Fig. 3 Solar farm architecture
The panels under test in this project are all of the same type with a module named HJM80M-12 which is connected off-grid with the manufacturer specifications as depicted in Table 1.

Table 1. Panel specifications

\begin{tabular}{|l|c|}
\hline Electrical rating & $\begin{array}{l}\text { At } \mathrm{STC} \quad(\mathrm{AM} 1.5, \\
\left.1000 \mathrm{~W} / \mathrm{m}^{2} \text { at } 25^{\circ} \mathrm{C}\right)\end{array}$ \\
\hline Maximum power & $80 \mathrm{~W}$ \\
\hline OC voltage $\left(\mathrm{V}_{\text {oc }}\right)$ & $21.9 \mathrm{~V}$ \\
\hline SC current $\left(\mathrm{I}_{\mathrm{sc}}\right)$ & $4.95 \mathrm{~A}$ \\
\hline Voltage at $\mathrm{P}_{\max }\left(\mathrm{V}_{\mathrm{mp}}\right)$ & $17.6 \mathrm{~V}$ \\
\hline Current at $\mathrm{P}_{\max }\left(\mathrm{I}_{\mathrm{mp}}\right)$ & $4.58 \mathrm{~A}$ \\
\hline Max. system voltage & $\mathrm{DC} 1000 \mathrm{~V}$ \\
\hline Weight & $8.5 \mathrm{~kg}$ \\
\hline Dimensions & $1200 \times 540 \times 35 \mathrm{~mm}$ \\
\hline Cell technology & Mono-Si \\
\hline
\end{tabular}

The NodeMCU is a microcontroller, which contains a small chip called ESP8266 (Barai, Biswas, \& Sau, 2017). This type of microcontroller has a built-in USB connector and a set of output pins as shown in Fig. 4.

\subsection{Server-Side Components}

The server-side is a software installed on a computer or any other devices such as Tab or phone. In this paper, we proposed a dedicated website designed with PHP and HTML scripted language in addition to the cloud database to store the measured data. We will use the ThingSpeak cloud database that is supported by MathWorks which can store data over the internet using Arduino, NodeMCU, Raspberry Pi or any other suitable hardware (Pasha, 2016). The monitoring website is designed to display PV panels status. When the designed system starts running, it will begin to collect data from panels via sensors and these data will be sent to the cloud server via wireless modules that are able to connect to the gateway with IP address. In order to retrieve and display these monitored data in the control room or central room, the user needs a GUI page to allow viewing of all data in an easy form. For this purpose, a PHP scripted language has been used to design such GUI website (Kumar, 2011). The website is designed for displaying recorded data from the cloud server. PHP scripting language with HTML, CSS, bootstrap, and JavaScript are used to design a complete website in order to get realtime monitoring user interface. 


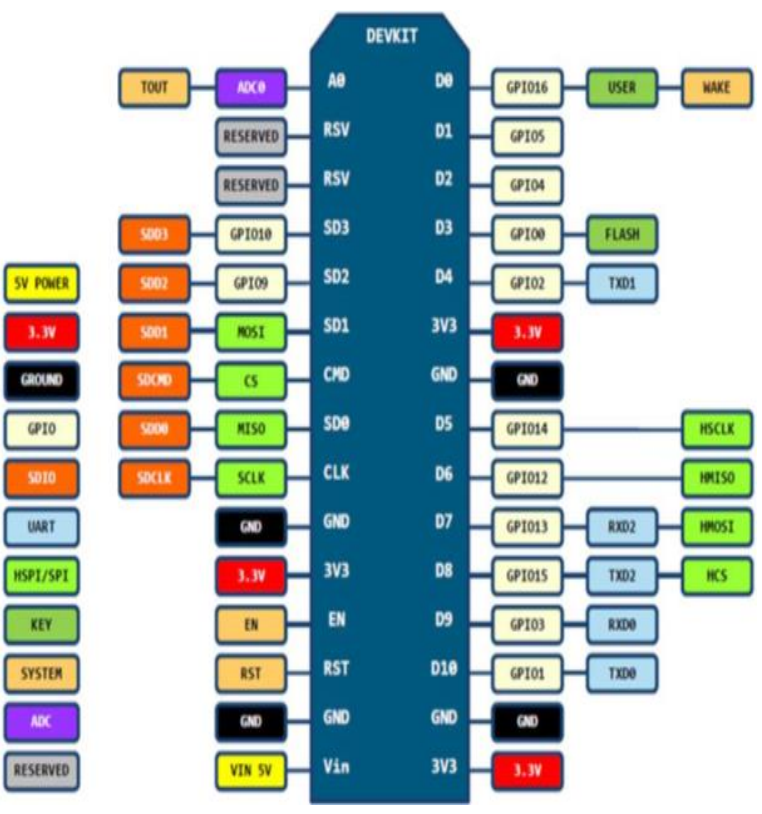

Fig. 4 NodeMCU pins definition

The website consists of the login page, the home page, about page, and panels monitoring pages.

- Login page: this is a startup page of the website. When a user opens the website, he or she should sign in a username and password in order to log in to the website page as depicted in Fig. 5.

- Home page: this page displays the current temperature and humidity of the solar farm that is collected from humidity and temperature sensors as shown in Fig. 6.

- Panels monitoring pages: these pages are the most important pages in the system. When a user logs into the system, he or she can go to these pages to display the status of solar panels. The system was designed for the 20 panels in the MST. These panels have been installed as five strings in parallel form. Each string consisting of four panels connected in series. The website displays each string data in a separate page in order to facilitate viewing data. The web page in Fig. 7 shows string 1 for panel 1 parameters (voltage, current, and power).

\section{MONITORING SYSTEM CONNECTION}

The proposed system consists of a client side and a server side. The client-side consists of hardware and software to program these hardware components. The connection between these components is shown in Fig. 8. The data collected from sensors will be sent to the cloud server by the NodeMCU to allow real-time monitoring (Barai et al., 2017). The flow chart of the system is shown in Fig. 9. At first, sensors sense data, the multiplexer selects one input sensor, NodeMCU microcontroller reads these data and sends them to cloud using the ESP8266 Wi-Fi module and then sends signals to the multiplexer to switch to another sensor.

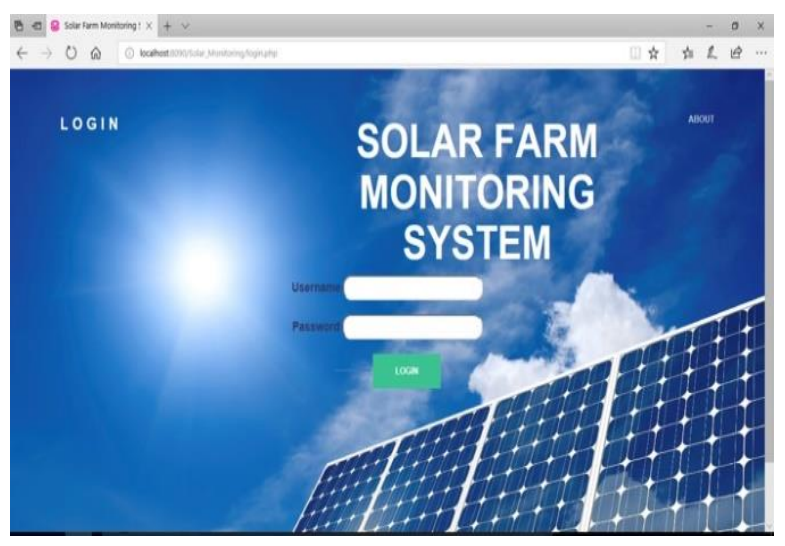

Fig. 5 User login page

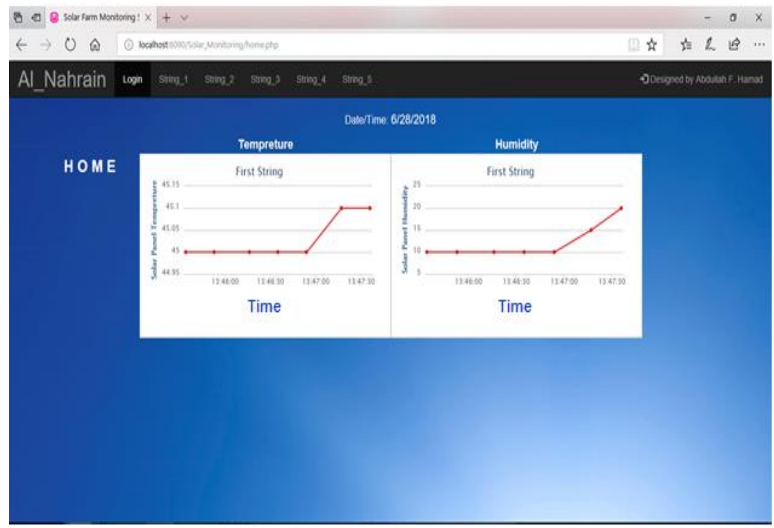

Fig. 6 Home page

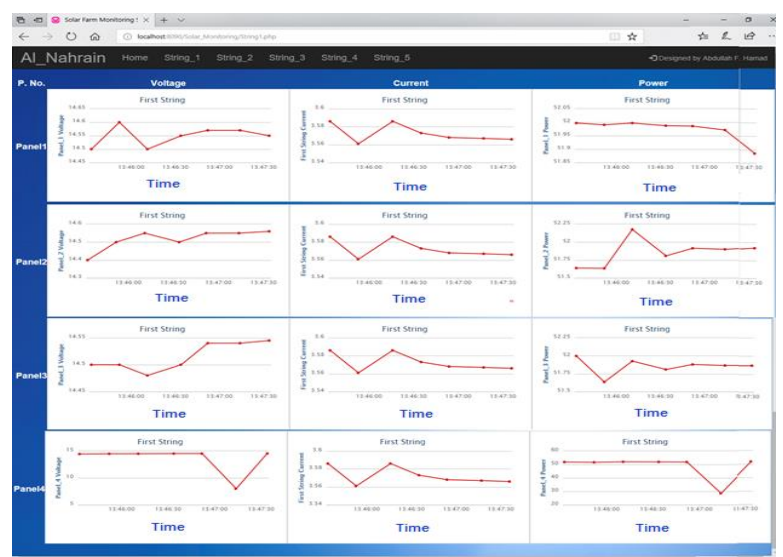

Fig. 7 String 1 monitoring page 


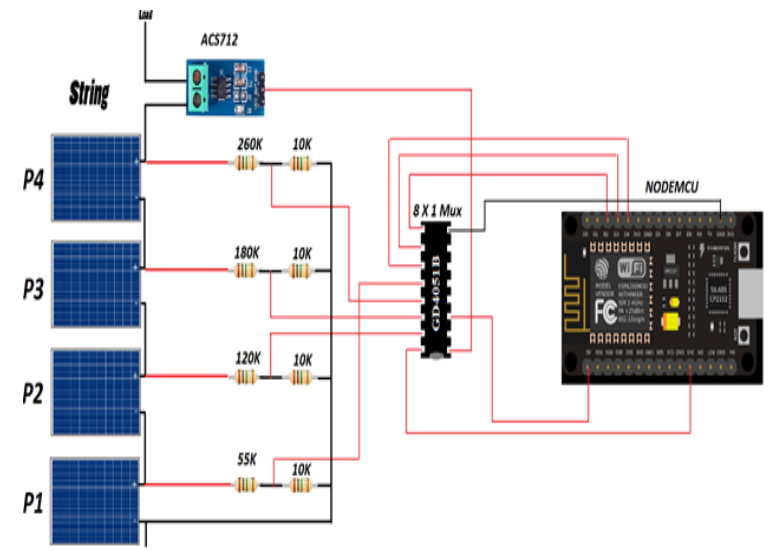

Fig. 8 System connection for one string

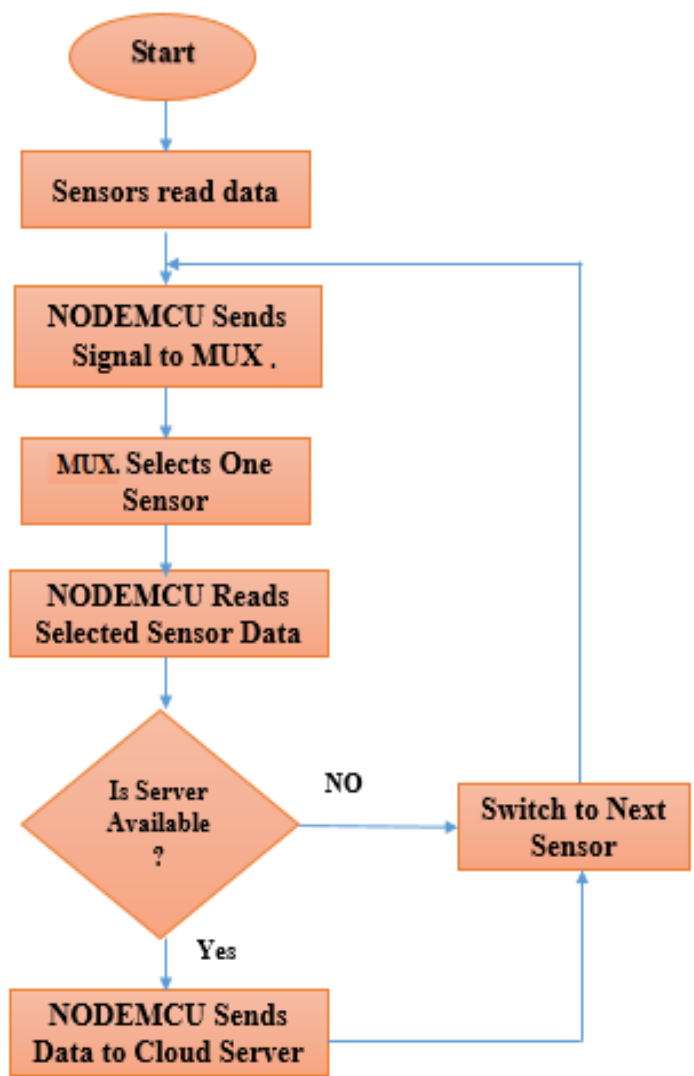

Fig. 9 Flow chart of the proposed monitoring system

\section{MONITORING SYSTEM IMPLEMENTATION}

Fig. 10a shows the proposed monitoring system installed on these panels. The voltage sensors are connected in parallel with each panel to calculate the open circuit voltage and current sensors are connected in series with each string to calculate short-circuit current. The power of the solar panel is calculated by multiplying the voltage by the current of the string to which that panel belongs. Fig. 10b shows the practical connection voltage sensors and current sensor on one string. The humidity and temperature sensor installed separately near the solar farm as shown in Fig. 10c.

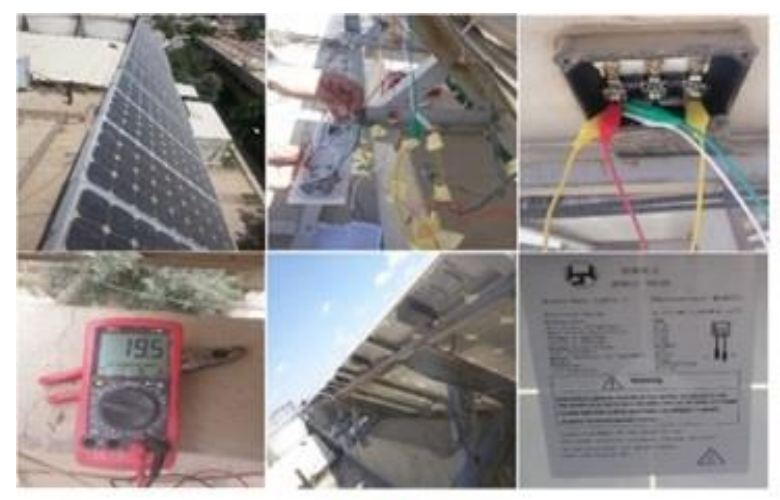

Fig. $10(a)$

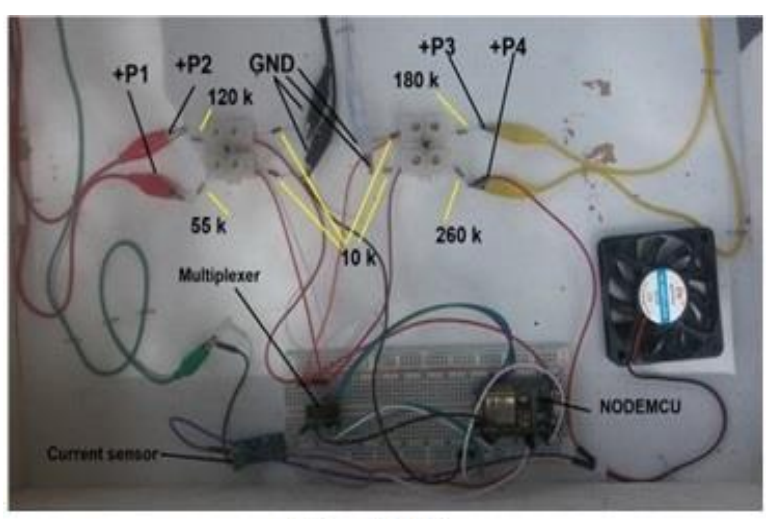

Fig. 10 (b)

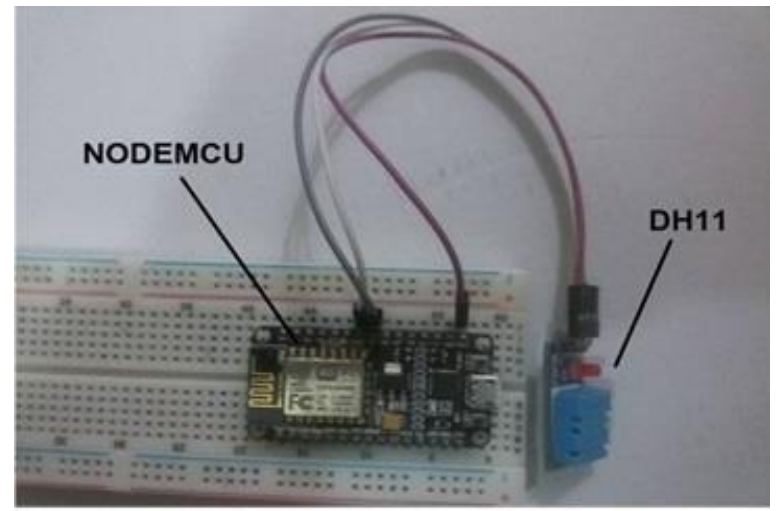

Fig. 10 (c)

Fig. 10

(a) The proposed monitoring system,

(b) Voltage and current sensors

(c) Humidity and temperature sensor 


\section{RESULTS}

The collected data will be sent to the cloud server and the designed website displays these data in an interface form. Fig. 11 shows the recorded test data of panel 4 from the cloud database for the following five design parameters; voltage, current, power, temperature, and humidity respectively.

This test was carried out on Thursday, June 28, 2018, on Solar Station installed in the MST. With a focus on panel 4 data, we found that at 13:45:34, the temperature is $45^{\circ} \mathrm{C}$, humidity is $10 \%$, voltage is $14.45 \mathrm{~V}$, the current is $3.586 \mathrm{~A}$, and the power is $51.817 \mathrm{~W}$. These recorded data show that panel 4 is working properly by comparing these data with the datasheet data of this panel. Moreover, to simulate two faulty conditions, we added some dust on this panel for the purpose of reducing the received radiation and increased the humidity and temperature by holding the humidity and temperature sensor by wet hand at 13:47:14. We observed that the newly recorded parameters are as follows: (temperature $=45.1^{\circ} \mathrm{C}$, humidity $=15 \%$, voltage $=8 \mathrm{~V}$, current $=3.567 \mathrm{~A}$, and power $=28.536$ W).By comparing these data with the datasheet, we see that this panel is affected by some faults leading to a decrease in its power-producing capability. These data were in fact displayed on a remote laptop connected to the Internet in the College of Engineering, Al-Nahrain University on a different site location from MST.

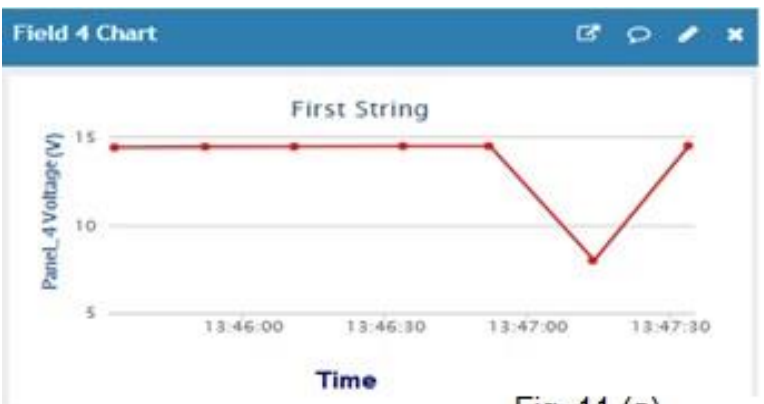

Fig. 11 (a)

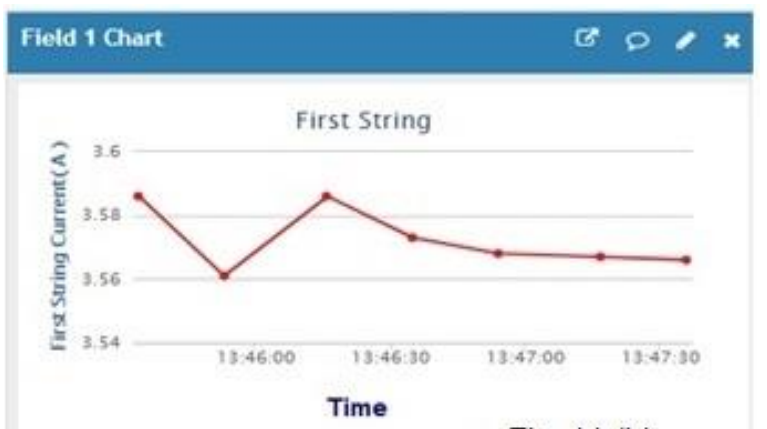

Fig. 11 (b)

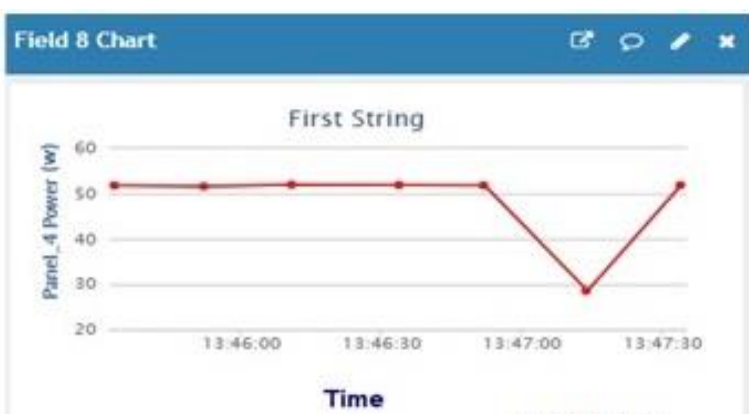

Fig. $11(c)$

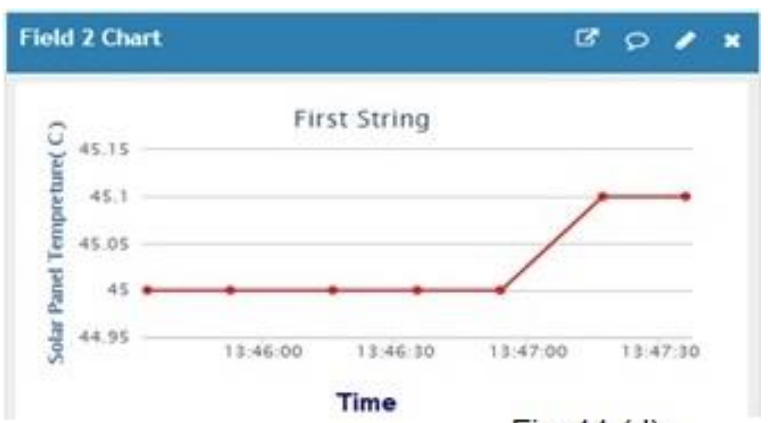

Fig. 11 (d)

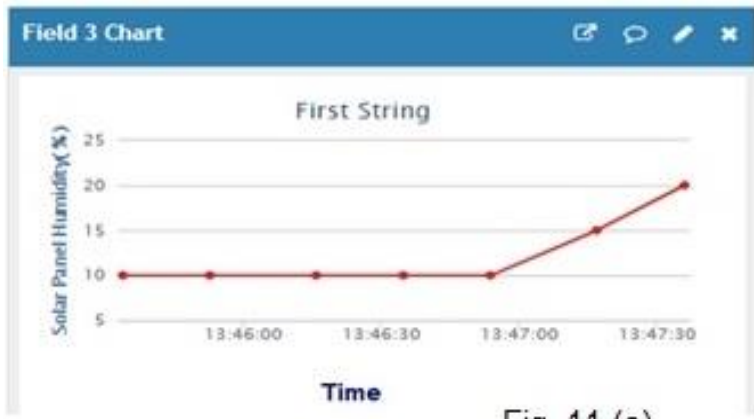

Fig. 11 (e)

Fig. 11

(a) The recorded voltage of panel 4.

(b) The recorded current of string 1.

(c) Recorded power of panel 4.

(d) Recorded Temperature. (e) Recorded humidity

It must be emphasized that the Internet speed is an important factor to determine publishing data efficiency. In this test with an Internet speed of about $400 \mathrm{Kbps}$, the proposed monitoring system can send the status of each sensor to the cloud server with an average delay of 20 seconds for each panel status. This delay time can be reduced by increasing Internet speed. The cost of designing this monitoring system must be taken into consideration. Table 2 shows the estimated cost of the hardware components being used in this project. 
Table 2. Estimated components cost

\begin{tabular}{|l|r|r|r|}
\hline \multicolumn{1}{|c|}{$\begin{array}{c}\text { Component } \\
\text { Category }\end{array}$} & $\begin{array}{c}\text { Unit } \\
\text { cost } \\
\text { (USD) }\end{array}$ & Qty & $\begin{array}{c}\text { Cost } \\
\text { (USD) }\end{array}$ \\
\hline NodeMCU & 8.00 & 5 & 40.00 \\
\hline $\begin{array}{l}\text { Current sensor } \\
\text { (ACS712) }\end{array}$ & 2.00 & 5 & 10.00 \\
\hline $\begin{array}{l}\text { Temperature and } \\
\text { Humidity sensor } \\
\text { (DHT11) }\end{array}$ & 1.00 & 1 & 1.00 \\
\hline Resistors (260 k $\Omega)$ & 0.05 & 5 & 0.25 \\
\hline Resistors (180 k $\Omega$ ) & 0.07 & 5 & 0.35 \\
\hline Resistors (120 k $\Omega)$ & 0.08 & 5 & 0.40 \\
\hline Resistors (55 k $\Omega)$ & 0.10 & 5 & 0.50 \\
\hline Resistors (10 k $\Omega$ ) & 0.20 & 20 & 4.00 \\
\hline $\begin{array}{l}\text { Multiplexer } \\
\text { (GD4051B) }\end{array}$ & 0.40 & 5 & 2.00 \\
\hline Estimated total cost & & & $\$ 58.50$ \\
\hline
\end{tabular}

\section{CONCLUSION}

Solar farms have become one of the practical solutions for harnessing solar energy. In this paper, we proposed a low-cost monitoring system for PV panels based on a cloud database where the big data of the status of the solar panels are stored and displayed by a dedicated GUI website designed by PHP, HTML, and CSS programming languages. Due to its simplicity, this proposed system makes it easier to monitor PV panels and detect their faults in real time. The proposed monitoring system was successfully implemented on an existing solar station that consists of 20 panels. The practically implemented system could read all the essential PV parameters and send them to the central room to be displayed by a GUI website that enables the user to view them in a simple form. As a future development of the project, the designed system is to be tested on a solar farm having around 540 PV panels in the Ministry of Industry and Minerals of Iraq / Center for Research and Renewable Energies.

\section{WORKS CITED}

Abid, A., Obed, A., \& Al-Naima, F. (2018). Detection and control of power loss due to soiling and faults in photovoltaic solar farms via a wireless sensor network. International Journal of Engineering \& Technology, 7(2), 718-724. https://doi.org/10.14419/ijet.v7i2.10987

Banu I-V, I. (2012). Modeling and simulation of photovoltaic arrays. World Energy System Conference, 14(1), 6.

Barai, S., Biswas, D., \& Sau, B. (2017). Estimate Distance Measurement using NodeMCU ESP8266 based on RSSI Technique, 170-173. https://doi.org/10.1109/CAMA.2017.8273392

Bellia, H., Youcef, R., \& Fatima, M. (2014). A detailed modeling of photovoltaic module using MATLAB. NRIAG Journal of Astronomy and Geophysics, 3(1), 53-61. https://doi.org/10.1016/j.nrjag.2014.04.001

Desmond, T., Seng, L. C., \& Leong, V. (2016). Power Divider Rule : AC circuit analysis, 39(5), 274-283.

Guerriero, P., Vallone, G., Primato, M., Napoli, F. Di, Nardo, L. Di, Alessandro, V., \& Daliento, S. (2014). A wireless sensor network for the monitoring of large PV plants, 960-965.

Kandil, K. M., Altouq, M. S., Al-asaad, A. M., Alshamari, L. M., Kadad, I. M., \& Ghoneim, A. A. (2011). Investigation of the Performance of CIS Photovoltaic Modules under Different Environmental Conditions. Smart Grid and Renewable Energy, 02(04), 375-387. https://doi.org/10.4236/sgre.2011.24043

Kaur, D., \& Kaur, M. (2017). An Approach of Mobile Wireless Sensor Network for Target Coverage and Network Connectivity with Minimum Movement. International Research Journal of Engineering and Technology(IRJET), 4(1), 1275-1280. Retrieved from https://www.irjet.net/archives/V4/i1/IRJET-V4I1228.pdf

Kumar, B. A. (2011). Solar Power Systems Web Monitoring. The 2nd Symposium on Renewable Energy Technologies (SoRET), October 2011, Raiwai, Fiji, (October).

Matin, M. A., \& Islam, M. M. (2012). Overview of Wireless Sensor Network. Wireless Sensor Networks - Technology and Protocols, 3-24. https://doi.org/10.5772/49376

Mohapatra, A., Nayak, B. K., \& Mohanty, K. B. (2013). Comparative study on single diode photovoltaic module parameter extraction methods. Proceedings of 2013 International Conference on Power, Energy and Control, ICPEC 2013, (February), 30-34. https://doi.org/10.1109/ICPEC.2013.6527619

Nagalakshmi, R., Babu, B. K., \& Prashanth, D. (2014). Design and Development of a Remote Monitoring and Maintenance of Solar Plant Supervisory System, 3(12), 9382-9385. 
Papageorgas, P., Piromalis, D., Antonakoglou, K., Vokas, G., Tseles, D., \& Arvanitis, K. G. (2013). Smart solar panels: In-situ monitoring of photovoltaic panels based on wired and wireless sensor networks. Energy Procedia, 36, 535-545. https://doi.org/10.1016/j.egypro.2013.07.062

Pasha, S. (2016). Thingspeak Based Sensing and Monitoring System for loT with Matlab Analysis. International Journal of New Technology and Research(IJNTR), 2(6), 19-23.

Purohit, N. L. (2015). Data Acquisition of Solar Power Plant Using Scada System, 23(4), 189-194.

Tejwani, R., Kumar, G., \& Solanki, C. (2014). Remote monitoring for solar photovoltaic systems in a rural application using GSM voice channel. Energy Procedia, 57(1959), 1526-1535. https://doi.org/10.1016/j.egypro.2014.10.145

Thangarajah, A., Wongkaew, B., \& Ekpanyapong, M. (2014). Implementation of Auto Monitoring and ShortMessage-Service System via GSM Modem. ljcer, 3(2), 63-68. Retrieved from http://w.ijcer.org/index.php/ojs/article/view/528

Tomar, R., \& Basak, P. (2016). Modeling and Simulation of Photovoltaic Module to Study the Effects of Variation in Irradiance and Temperature, 6678-6684. https://doi.org/10.15662/IJAREEIE.2016.0508012

Zhang, Z., Wu, P., Han, W., \& Yu, X. (2017). Remote monitoring system for agricultural information based on wireless sensor network. Journal of the Chinese Institute of Engineers, 40(1), 75-81. https://doi.org/10.1080/02533839.2016.1273140

Received for publication: 20.06.2019

Revision received: $\quad 27.06 .2019$

Accepted for publication: 10.07.2019

\section{How to cite this article?}

Style - APA Sixth Edition:

Al-Naima, F., \& Hamad, A. (2019, July 15). A Low-cost Solar Farm Monitoring System Based on Cloud Database. (Z. Cekerevac, Ed.) MEST Journal, 7(2), 1-8. doi:10.12709/mest.07.07.02.01

Style - Chicago Sixteenth Edition:

Al-Naima, Fawzi, and Abdullah Hamad. 2019. "A Low-cost Solar Farm Monitoring System Based on Cloud Database." Edited by Zoran Cekerevac. MEST Journal (MESTE) 7 (2): 1-8. doi:10.12709/mest.07.07.02.01.

Style - GOST Name Sort:

Al-Naima Fawzi and Hamad Abdullah A Low-cost Solar Farm Monitoring System Based on Cloud Database [Journal] // MEST Journal / ed. Cekerevac Zoran. - Belgrade - Toronto : MESTE, July 15, 2019. - 2 : Vol. 7. - pp. 1-8.

\section{Style - Harvard Anglia:}

Al-Naima, F. \& Hamad, A., 2019. A Low-cost Solar Farm Monitoring System Based on Cloud Database. MEST Journal, 15 July, 7(2), pp. 1-8.

Style - ISO 690 Numerical Reference:

A Low-cost Solar Farm Monitoring System Based on Cloud Database. Al-Naima, Fawzi and Hamad, Abdullah. [ed.] Zoran Cekerevac. 2, Belgrade - Toronto : MESTE, July 15, 2019, MEST Journal, Vol. 7, pp. 1-8. 